Analysis

\title{
The implicit value of tree cover in the U.S.: A meta-analysis of hedonic property value studies ${ }^{2}$
}

\author{
Shyamani D. Siriwardena ${ }^{\mathrm{a}, *, 1}$, Kevin J. Boyle ${ }^{\mathrm{b}, 1}$, Thomas P. Holmes ${ }^{\mathrm{c}, 1}$, P. Eric Wiseman ${ }^{\mathrm{d}, 1}$ \\ a Department of Forest Resources and Environmental Conservation, 313 Cheatham Hall (0324), Virginia Tech, Blacksburg, VA 24061, USA \\ b Virginia Tech Program in Real Estate, 420 Bishop-Favrao Hall (0715), Virginia Tech, Blacksburg, USA \\ c USDA Forest Service, Southern Research Station, Research Triangle Park, NC, USA \\ d Department of Forest Resources and Environmental Conservation, Virginia Tech, Blacksburg, USA
}

\section{A R T I C L E I N F O}

\section{Article history:}

Received 18 March 2015

Received in revised form 1 March 2016

Accepted 3 April 2016

Available online 4 May 2016

\section{Keywords:}

Hedonic valuation

Tree canopy cover

Community forestry

Forest matrix

Climate change

\begin{abstract}
A B S T R A C T
Trees in residential neighborhoods and communities provide benefits for homeowners that are capitalized into residential property values. In this paper, we collected data from hedonic property value studies and merged these data with ancillary spatial data describing forest and socio-economic characteristics surrounding each study area to conduct a meta-analysis of the impact of tree canopy cover on the value of residential properties. The meta-analysis suggests that property-level tree cover of about $30 \%$ and county-level tree cover of about $38 \%$ maximize the implicit price of tree cover in property values. Currently, tree cover in the original study areas was about $14 \%$, on average, around or near study properties. The empirical results, therefore suggest under investment of tree cover on private property from the perspective of individual property owners and from a societal perspective. The findings also have implications for community forest programs regarding planting trees and protection of mature trees to address potential changes in tree abundance, species diversity and stand age due to development and climate change.
\end{abstract}

(c) 2016 Elsevier B.V. All rights reserved.

\section{Introduction}

Tree cover, the land area covered by tree crowns, in residential neighborhoods is an environmental attribute that provides a suite of ecosystem services (e.g., landscape esthetics, wildlife habitat, energy conservation, stormwater control) to homeowners and communities (Nowak et al., 2010). Most trees in urban and suburban neighborhoods are located on private property where the costs of tree planting and maintenance are borne by homeowners, while the benefits of trees can be enjoyed by the greater community. The disparity between who pays the costs (homeowners) and who receives the benefits from trees on privately-owned property (homeowners and the community) suggests that the level of tree cover on privately-owned land may be socially sub-optimal. A better understanding of the costs and benefits of trees, within the context of multiple social-ecological settings (Pickett et al., 2011), can help community planners design tree planting and

\footnotetext{
it This research was supported by the Southern Research Station of the U.S. Forest Service (12-JV-11330143-106) and Virginia Agricultural Experimental Station.

* Corresponding author.

E-mail addresses: shyadil@vt.edu (S.D. Siriwardena), kjboyle@vt.edu (K.J. Boyle), tholmes@fs.fed.us (T.P. Holmes), pwiseman@vt.edu (P.E. Wiseman).

${ }^{1}$ Siriwardena, Boyle and Wiseman are PhD candidate, Professor and Associate Professor, respectively, at Virginia Tech. Holmes is an Economist with the U.S. Forest Service.
}

protection programs to improve the quality of life for people and justify the costs of such programs.

Although the economic benefits of tree canopy cover (tree cover hereafter) are not directly priced, one component of their economic value, the implicit value to property owners, can be estimated using hedonic property value models. Hedonic models decompose the total price paid for a property into the "implicit" prices of property characteristics. The implicit price of a characteristic, such as the amount of tree cover, is the amount home buyers pay for a small change in the level of the characteristic, holding all other property characteristics constant (Taylor, 2003).

Previous hedonic studies have found that the value of forested areas varies with the degree of forest fragmentation and urbanization. For example, larger forest patches are valued more in the urban core, while a more fragmented and diverse landscape is preferred in ruralurban interfaces (Cho et al., 2008). Trees are valued more in areas where they are scarce and less so in heavily forested areas (Netusil et al., 2010). Large trees with full canopies have been shown to enhance retail settings (Wolf, 2004) and large shade trees are preferred by residents in areas with hot summers (Schroeder et al., 2006). Temporal variations of the value of trees has also been observed by Cho et al. (2009) where the amenity value of trees increased over time with declining forest patch size and density.

Forested areas can also present real or perceived risks that lower property values. Locations that have experienced or where there are 
perceived risks from forest fires or invasive pests attacking trees may result in homes located near forested areas having lower values (Holmes et al., 2006; Huggett, 2003; Kim and Wells, 2005; Stetler et al. 2010). The effects on property prices from risks due to forest pest infestations may be widespread in the United States: the hemlock wooly adelgid in the northeast, the emerald ash borer in the Midwest, and the mountain pine beetle in the west. The forest-fire effect may be more geographically concentrated in the western United States where there are frequent large forest fires that pose risks to residences. In addition, a suite of socio-economic, cultural, and lifestyle factors may influence the diversity and spatial extent of trees in urban and suburban landscapes (Hope et al., 2003; Troy et al., 2007).

In this paper, we present a meta-analysis of hedonic property value studies that have estimated the relationship between tree cover and residential property values across the U.S. A meta-analysis is the systematic examination of research results from multiple studies to learn what the results of the studies collectively imply. In addition, metaanalyses allow insights that may not be possible from a single study. For any given study, the range of an attribute that is observed to support estimation may be limited while greater variation may be observed across multiple studies. For example, in the context of the current application, a limited range of tree cover might be observed for any individual study and larger variation in tree cover might be observed over multiple studies. In addition, a meta- analysis can consider geographic and demographic differences in studies that are fixed for any single study, e.g., tree cover and the local population in the area where the studies were conducted. Thus, the meta-data from previous hedonic studies of tree cover are augmented with auxiliary county-level tree cover and tree age data from the U.S. Forest Service. Spatial variation across studies is also controlled by including U.S. Bureau of Census data on population and income.

The meta-analysis includes two measures of tree cover: (1) tree cover on and near residential properties and (2) county-level cover in the county where the residential properties are located. Linear and square terms for these variables allow for nonlinear relationships between implicit prices and tree cover. The empirical results indicate that both measures of tree cover have positive, nonlinear, and statistically significant effects on residential property values. The results reveal that the density of county-level tree cover that maximizes implicit prices (38\%) is greater than the density of property-level tree cover on or near residential properties that maximizes implicit prices (30\%). This pattern of results supports the intuition that the investment of tree cover on private land may be sub-optimal from a social perspective.

We suggest that this type of assessment and the consequent knowledge of the implicit value of tree cover are of timely importance in light of two trends that can acutely affect the extent, composition, and productivity of urban and peri-urban forests in the coming decades: climate change and urbanization. It is thought that climate-induced migration and redistribution of tree species might extirpate some tree species in some areas as well as cause shifts in tree diversity, stand age, species predominance, and the overall number of trees (Iverson and Prasad, 2001; Prasad et al., 2009; Woodall et al., 2009). In addition, changes in climate may increase the frequency and severity of forest fires, insect and disease outbreaks, and extreme weather events that can affect tree health and abundance and ultimately the extent of tree cover (Dale et al., 2001; Bentz, 2008; Frankel, 2008). Compounding climate change effects is the loss of trees to development and urbanization. Nowak and Greenfield (2012) looked at 20 major U.S. cities during the mid to late 2000s and found that tree cover was declining at a rate of about $0.27 \%$ per year while impervious surface cover was increasing at about $0.31 \%$ per year. When the researchers extrapolated the loss rate across urban areas of the conterminous United States, they determined that aggregate annual loss of tree cover is substantial, about 7900 ha or roughly 4 million trees. Communities attempting to stabilize and enhance tree cover, particularly on private residential property where the bulk of existing tree cover and tree planting opportunities exist, need objective information on the economic value of tree cover to help justify their efforts.

\section{Conceptual Framework}

Hedonic price functions of residential property sales represent the sale prices of properties, agreed to by willing sellers and buyers, as functions of property characteristics:

$H P=f(P C, S C, L C, E C: \beta)+e$

where $H P$ is the sale price of properties, $P C$ is property characteristics (e.g., acreage), SC is structure characteristics (e.g., square feet of living area in a residence), $L C$ is location characteristics (e.g., proximity to schools), EC is environmental characteristics (e.g., tree cover), $\beta$ is a vector of coefficients to be estimated, and $e$ is a random error term. The implicit price $\left(I P_{i}\right)$ of any individual characteristic $\left(c_{i}\right)$ is:

$I P_{i}=\frac{\partial H P(\cdot)}{\partial C_{i}}$

The implicit price for tree cover is the dependent variable used in the meta-analysis reported here.

The dependent variable in a meta-equation is often referred to as the effect size. Although the standard practice is to explain variation in effect sizes using only data on characteristics reported in the original study, recent meta-analyses have used characteristics describing the spatial context in the area surrounding the original study sites to enhance explanatory power (Ghermandi and Nunes, 2013; Johnston et al., 2014). In the current study, the effect size is the implicit price for tree cover on and near a residential property; the implicit price constitutes the effect on property sale prices from a change in tree cover. Because the implicit value of tree cover may be influenced by the condition and abundance of trees in the broader geographic area where people work, shop, and recreate, we also include a vector of contextual ancillary variables in the meta-analysis. Following this logic, a general specification for the meta-equation is:

$I P=g($ Study_Char, Context_Char $; \theta)+\varepsilon$

where Study_Char is a vector of characteristics that describes original studies, Context_Char is a vector of characteristics that describes the spatial context surrounding the original study locations, $\theta$ is a vector of coefficients to be estimated, and $\varepsilon$ is a random error term.

When reviewing the hedonic studies that included tree cover as a property characteristic, we found some studies that estimated positive implicit prices, some that revealed negative implicit prices, and some that found both positive and negative implicit prices. Thus, the first step in the analysis is to estimate a selection model to see if a set of study and context characteristics influence whether positive or negative implicit prices are observed for tree cover (Heckman, 1979). The selection model is:

$\operatorname{Pr}(I P>0)=h\left(\right.$ Study_Char $^{\prime}$, Context_Char' $\left.; \gamma\right)+\omega$

$I P^{+}=g^{+}\left(\right.$Study_Char, Context_Char $\left.; \theta^{+}\right)+\varepsilon^{+}$

where $\omega$ is a random error term in the selection Eq. (4a) to predict if studies report positive or negative implicit prices, the apostrophes in the selection equation indicate different characteristics are included in the selection Eq. (4a) and meta-equation (4b), the plus symbol in Eq. (4b) indicates the meta-equation is estimated solely for positive implicit price estimates $(I P>0)$, and $\gamma$ and $\theta^{+}$are vectors of coefficients to be estimated. Eq. (4a) predicts the probability that a positive implicit price is estimated (versus negative) and Eq. (4b) is the meta-equation for positive implicit prices. The selection model allows a test of whether 
including only positive implicit price estimates will affect coefficient estimates in the meta-equation.

\section{Data}

An extensive search of the literature identified 56 hedonic property value studies that included measurements of either forest or tree characteristics as explanatory variables. ${ }^{2}$ Most of these studies (44) were conducted in the U.S., although we also identified studies conducted in Canada, China, Denmark, Finland, France, and the United Kingdom. The studies included peer-reviewed journal articles, MS and Ph.D. theses, and working papers. There was no date restriction on the search, and the search identified studies that were conducted over a span of 35 years.

From the global set of studies, we selected studies to be included in the meta-analysis using the following criteria:

1st. Hedonic price functions must be based on sales of residential properties (i.e., studies based on commercial sales, rental rates, tax assessments, etc. were excluded.)

2nd. Studies must have been conducted in the U.S. This criterion facilitated the compilation of ancillary variables. In addition, there are only a small number of studies conducted outside of the United States and these studies were conducted in a number of different countries.

3rd. The unit of measurement for trees must be tree cover on or surrounding each sold property, while excluding studies based on other forest metrics (e.g., distance from homes to the nearest forest). ${ }^{3}$

4th. Studies must include adequate information to permit calculation of the implicit price and mean level of tree cover for the study area.

These conditions reduced the number of usable studies to 15 . Of these studies, 13 included multiple implicit-price estimates resulting in a total of 106 observations for the meta-analysis. ${ }^{4}$ All implicit-price estimates from each study are included in the data used to estimate the meta-equation with one exception. Any observation related to unhealthy trees due to disturbances such as forest fires or invasive pest outbreaks is not included in the analysis (e.g., observations for defoliated and dead hemlocks in Holmes et al. (2010) are excluded). Thus, the negative implicit prices would not be the result of trees with compromised structure or health.

The hedonic studies gleaned from the literature and those selected for the meta-analysis are broadly distributed across the United States (Fig. 1). As noted above, the data include observations on the implicit value of tree cover as an amenity (positive implicit price estimates; $\mathrm{n}=68$ ) and as a disamenity (negative implicit price estimates; $\mathrm{n}=$ 38). Eight studies reported both positive and negative implicit price estimates.

To satisfy the condition that the estimated meta-equation must be based on a dependent variable measuring a common effect size, the marginal implicit prices (IP) for all included observations was measured as the change in property prices due to a $1 \%$ change in tree cover. Studies used a variety of functional specifications of the hedonic equation (see "Model" column in Table 1). For the studies that specified a linear

\footnotetext{
2 The study identification process included a search of relevant databases including AgEcon Search, CABDirect, and Google Scholar. We appreciate a reviewer brings one study to our attention that was not revealed in this search.

${ }^{3}$ None of the other forest metrics were represented in a sufficient number of studies to support separate meta-analyses.

${ }^{4}$ Multiple observations come from studies that estimated more than one functional form of the hedonic price model, studies that estimated separate models for tree cover in multiple neighborhoods, and studies that estimated separate models for different forest types. For example, the Netusil et al. (2010) study provided 12 observations from quadratic and log-log models for tree cover at property and 5 sub-regions within the study area. Holmes et al. (2006) estimated four separate models for tree cover (parcel level, $0.1 \mathrm{~km}$ buffer, $0.5 \mathrm{~km}$ buffer, and $1 \mathrm{~km}$ buffer) for four different forest types, which resulted in 16 implicit-price estimates.
}

hedonic model as a function of the percentage of land area covered by tree cover, the coefficient estimate for this variable is simply the marginal implicit price (e.g., Dimke, 2008). Whenever other functional forms or other measures of tree cover were used in the hedonic model, an alternative approach was used to compute the implicit prices for a $1 \%$ change in tree cover.

Using a specification with the natural log of the sale price as the dependent variable in the hedonic equation as an example, let $\ln (P)=$ $\beta_{0}+\beta_{1} t c$, where $P$ is the sale price of properties, $t c$ is the tree cover measure, $\beta_{1}$ is the parameter estimate on tree cover, and $\beta_{0}$ is a "grand constant" that captures the influence of all other variables in the model specification. The steps to compute the implicit prices are:

Step 1: Calculate $\widehat{\beta_{0}}=\ln (\bar{P})-\beta_{1} \overline{t c}$, where $\bar{P}$ is the average sale price and $\overline{t c}$ is the average tree cover from observations used to estimate the study-specific hedonic equation.

Step 2: Using the computed value of $\widehat{\beta_{0}}$, calculate an adjusted housing price $\left(P^{A}\right)$ for a $1 \%$ increase in tree cover: $P^{A}=\exp \left(\widehat{\beta_{0}}+\left(\beta_{1} \overline{t c} * 1.01\right)\right)$.

Step 3: Calculate the marginal implicit price as the difference between the adjusted and mean housing prices: $I P=P^{A}-\bar{P}$

This process is also applied to log-log models (e.g., Netusil et al. 2010) and quadratic functional forms (e.g., Stetler et al., 2010), while making appropriate adjustments to the calculation where necessary. The calculated implicit prices are then converted to 2013 dollars using the Consumer Price Index (U.S. Department of Labor, Bureau of Labor Statistics, 2015).

Percent tree cover (treecover) is the key independent variable in the meta-equation, but this variable was not measured as a percentage for all studies (see "UNIT" column in Table 1). The majority of studies reported tree cover as a percentage or proportion (e.g. Holmes et al., 2006; Dimke, 2008; Netusil et al., 2010), while others measure tree cover in area units (e.g., hectares, square meters or square feet). For latter studies, the tree cover measures are converted to percentages in the following manner:

Step 1: Calculate $A=\pi r^{2}$ where $A$ is the area of neighborhood with radius $r$ within which the tree cover is measured.

Step 2: Calculate treecover $=(B / A) * 100$ where $B$ is the mean tree cover within the respective neighborhood given in the original study.

This process is applied to calculate tree cover associated with differing buffer sizes used across and within studies (e.g. 250-m and 500-m buffer areas in Stetler et al., 2010).

Ancillary data used in estimating the meta-equation were obtained from five sources ${ }^{5}$ :

1. County-level data on the percent of tree cover were obtained from the U.S. Forest Service's Urban Forest Data (http://www.nrs.fs.fed. us/data/urban/, accessed 04.15. 2013).

2. The presence of forest invasive species or pathogens was obtained from the U.S. Forest Service's "Annual Insect and Disease Conditions Reports” (http://wwwtest.fs.fed.us/r8/foresthealth/publications/ pubs_conditions.shtml, accessed 08.13.2013).

3. The proportion of total county acreage in forest land partitioned into three age groups (young stands ( $<40$ years), medium-aged stands (40 to 119 years) and old stands ( $>120$ years) were obtained from U.S. Forest Service's Forest Inventory Data Online (FIDO) (http:// www.fia.fs.fed.us/tools-data/, accessed 04.16.2013).

4. County-level data on the annual number of days with temperatures exceeding $90^{\circ} \mathrm{F}$ were obtained from NOAA's National Climatic Data Center (http://www.ncdc.noaa.gov/cdo-web/, accessed 08.13.2013).

\footnotetext{
${ }^{5}$ For studies that used a county as the study area, ancillary data were collected for the county. For community-based studies, ancillary data for the county where the community is located were obtained. For studies that encompassed multiple counties, county level averages of ancillary data were used in the analysis.
} 


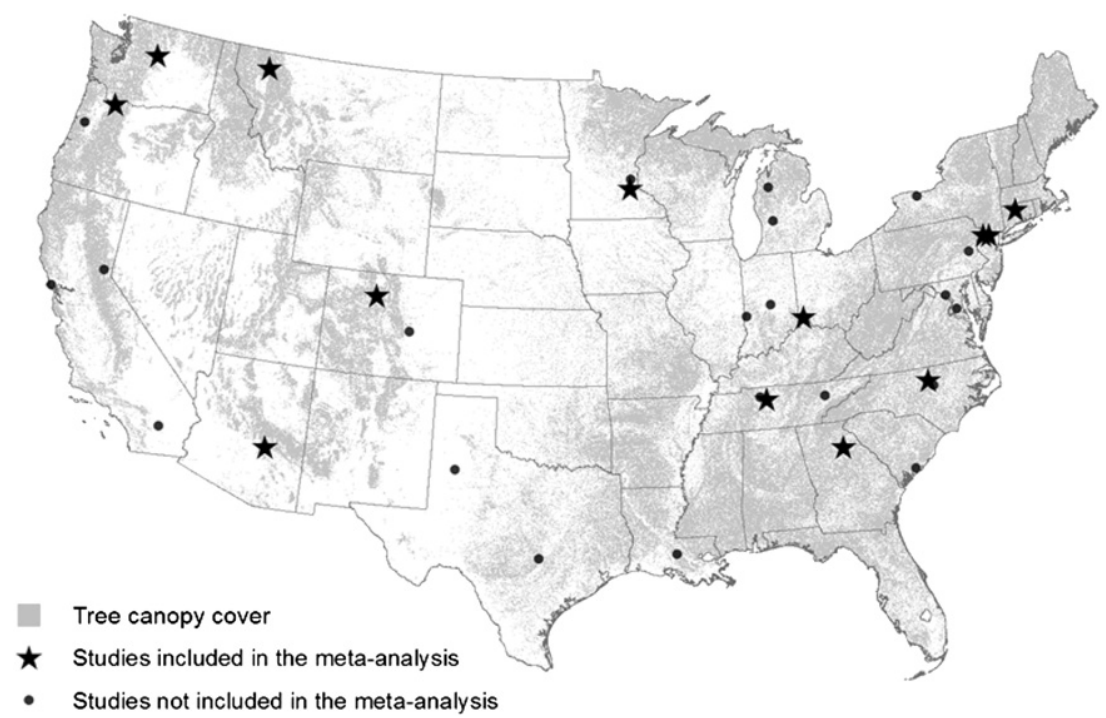

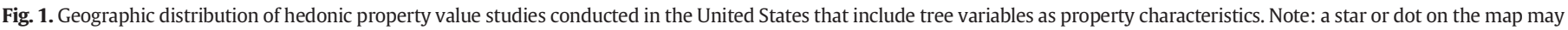
represent the location of more than one study. Tree canopy cover data are from Homer et al. (2007).

5. Data on socio-economic variables (population density and income) were obtained from the US Census Bureau (http://quickfacts. census.gov/qfd/index.html, accessed 06.12.2013).

The inclusion of these data in the meta-equation helps to control for spatial differences across the original hedonic studies that might influence estimated implicit prices beyond the characteristics of the hedonic studies themselves. These locational characteristics would likely be fixed (invariant) for any individual study.

This auxiliary data is important because previous studies have found evidence that tree cover in the vicinity of properties influences property values (e.g., Holmes et al., 2006, 2010; Sander et al. 2010; Netusil et al., 2010). For example, Cho et al. (2011) found that forest cover at a distance of 1.5 miles from a property had significant effects on property values. That is, thinking broadly of the community where people work, shop, and recreate, tree cover from a larger area than immediately around a property may affect property values.

The presence of forest pests can affect the quality of tree cover and are included to control for the potential negative effect on implicit prices. As implicit prices are excluded from studies that specially focused on the effects of forest pests on property values, this variable is best thought of as representing the risk that trees might be exposed to forest pests in the study areas.

The age of trees and temperature data are included to represent the amenity value of tree cover: older stands would have more tree cover and thus more shade, which might be more desirable in hotter climates. At the same time, older trees may develop structural defects, which might pose a risk (disamenity) of property damage or personal injury in the event of inclement weather.

Population and income can potentially affect whether trees are an amenity or disamenity and thereby affect the value that property

Table 1

Summary of hedonic property value studies used in the meta-analysis.

\begin{tabular}{|c|c|c|c|c|c|c|c|c|c|c|}
\hline \multirow[t]{2}{*}{ Publication } & \multicolumn{10}{|c|}{ Study characteristics } \\
\hline & Year & Positive & Negative & $\begin{array}{l}\text { Positive \& } \\
\text { significant }\end{array}$ & $\begin{array}{l}\text { Negative \& } \\
\text { significant }\end{array}$ & Unit & Model & $\begin{array}{l}\text { Average tree } \\
\text { cover }\end{array}$ & $\begin{array}{l}\text { Average county } \\
\text { cover }\end{array}$ & $\begin{array}{l}\text { Average selling } \\
\text { price }\end{array}$ \\
\hline Cho et al. & 2011 & 0 & 1 & 0 & 0 & $\begin{array}{l}\text { Area } \\
\text { (acres) }\end{array}$ & $\ln P=\beta_{0}+\beta_{1} \ln X$ & $24 \%$ & $36 \%$ & $\$ 233,588$ \\
\hline Coley & 2005 & 1 & 0 & 1 & 0 & Area $\left(\mathrm{ft}^{2}\right)$ & $\ln P=\beta_{0}+\beta_{1} X$ & $2 \%$ & $50 \%$ & $\$ 137,658$ \\
\hline Dimke & 2008 & 6 & 0 & 5 & 0 & Percentage & $P=\beta_{0}+\beta_{1} X$ & $26 \%$ & $27 \%$ & $\$ 186,947$ \\
\hline Drake-McLaughlin and & 2011 & 3 & 3 & 3 & 3 & Proportion & $\ln P=\beta_{0}+\beta_{1} X+\beta_{2} X^{2}$ & $25 \%$ & $45 \%$ & $\$ 24,576$ \\
\hline Netusil & & 4 & 2 & 2 & 2 & Proportion & $\begin{array}{l}\ln P=\beta_{0}+\beta_{1} X+\beta_{2} X^{2} \\
+\beta_{3} X Z\end{array}$ & & & \\
\hline Holmes et al. & 2006 & 10 & 6 & 7 & 2 & Percentage & $\ln P=\beta_{0}+\beta_{1} X$ & $8 \%$ & $66 \%$ & $\$ 494,894$ \\
\hline Holmes et al. & 2010 & 9 & 7 & 2 & 0 & Percentage & $\ln P=\beta_{0}+\beta_{1} X$ & $8 \%$ & $66 \%$ & $\$ 230,176$ \\
\hline Huggett & 2003 & 0 & 6 & 0 & 2 & Percentage & $\ln P=\beta_{0}+\beta_{1} X$ & $9 \%$ & $41 \%$ & $\$ 128,470$ \\
\hline Kim and Wells & 2005 & 1 & 1 & 1 & 1 & Area $\left(m^{2}\right)$ & $P=\beta_{0}+\beta_{1} X$ & $16 \%$ & $13 \%$ & $\$ 236,608$ \\
\hline Mansfield et al. & 2005 & 4 & 0 & 4 & 0 & Proportion & $P=\beta_{0}+\beta_{1} X$ & $30 \%$ & $54 \%$ & $\$ 196,699$ \\
\hline \multirow[t]{2}{*}{ Netusil et al. } & 2010 & 2 & 4 & 1 & 4 & Percentage & $\ln P=\beta_{0}+\beta_{1} X+\beta_{2} X^{2}$ & $14 \%$ & $45 \%$ & $\$ 236,961$ \\
\hline & & 5 & 1 & 3 & 1 & Percentage & $\ln P=\beta_{0}+\beta_{1} \ln X$ & & & \\
\hline Paterson and Boyle & 2002 & 3 & 0 & 0 & 0 & Percentage & $\ln P=\beta_{0}+\beta_{1} X$ & $61 \%$ & $52 \%$ & $\$ 295,048$ \\
\hline Price et al. & 2010 & 3 & 0 & 3 & 0 & Percentage & $\ln P=\beta_{0}+\beta_{1} X$ & $37 \%$ & $42 \%$ & $\$ 482,959$ \\
\hline Sander et al. & 2010 & 9 & 3 & 4 & 1 & Percentage & $\ln P=\beta_{0}+\beta_{1} X$ & $15 \%$ & $17 \%$ & $\$ 343,098$ \\
\hline Sander and Haight & 2012 & 5 & 1 & 4 & 0 & Percentage & $\ln P=\beta_{0}+\beta_{1} X$ & $14 \%$ & $16 \%$ & $\$ 380,596$ \\
\hline Stetler et al. & 2010 & 3 & 3 & 2 & 1 & Area (ha) & $\ln P=\beta_{0}+\beta_{1} X+\beta_{2} X^{2}$ & $14 \%$ & $50 \%$ & $\$ 310,132$ \\
\hline
\end{tabular}

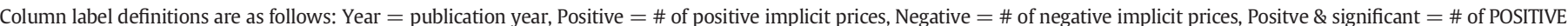

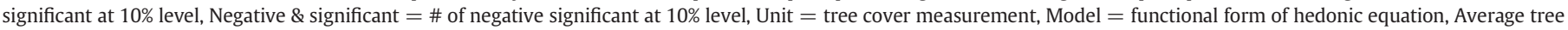

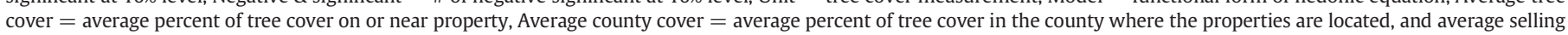
price $=$ average sale prices $(\$ 2013)$. 
purchasers place on tree cover. These socioeconomic variables and the other ancillary variables discussed above are likely to be fixed for any given hedonic study, but vary spatially across studies and provide the potential for a meta-analysis to provide insights on the value of tree cover beyond what can be observed in any single hedonic study.

\section{Model Specification}

The first model to be estimated is the selection model (Eqs. (4a) and (4b)). The selection Eq. (4a) is specified as:

$$
\begin{aligned}
h(Z ; \gamma)= & \Upsilon_{0}+\Upsilon_{1} \text { onprop }+\Upsilon_{2} \text { onprop } * \text { medtrees }+\Upsilon_{3} \text { onprop } * \text { oldtrees } \\
& +\Upsilon_{4} \text { onprop } * \text { invasive }+\Upsilon_{5} \text { onprop } * \text { temp }+\Upsilon_{6} \text { popdensity } \\
& +\Upsilon_{7} \text { medianincome }+\omega
\end{aligned}
$$

where $Z$ is a vector of study and context characteristics, and $\gamma$ is a vector of coefficients to be estimated. Each of the variables listed in Eq. (4a) is defined in Table 2. The dependent variable is binary and indicates if an implicit price is positive $(=1)$ or negative $(=0)$, and the selection equation is specified as a probit. The selection equation includes an explanatory variable (onprop) delineating whether the tree cover measure is on a property $(=1)$ or includes tree cover near a property $(=0)$, and this variable is interacted with other variables that may influence whether tree cover is viewed as an amenity or disamenity (medtrees, oldtrees, invasive, and temp). As noted previously, older trees may provide shade, but also potentially pose a greater risk of damage or injury. Invasive tree pests may affect the amenity value of trees and may increase the risk of tree breakage. Higher temperatures may create a desire for more tree shade for outdoor comfort and air conditioning savings, while lower temperatures may create a desire for less tree shade to allow winter sunlight to heat the home and hasten melting of ice and snow. Population density and median income are included to consider if these demographic characteristics affect whether tree cover is viewed as an amenity.

The meta-Eq. (4b) is specified as:

$$
\begin{aligned}
g^{+}\left(X, \theta^{+}\right)= & \theta_{0}^{+}+\theta_{1}^{+} \text {treecover }+\theta_{2}^{+} \text {treecover }^{2}+\theta_{3}^{+} \text {ctreecover } \\
& +\theta_{4}^{+} \text {ctreecover }^{2}+\theta_{5}^{+} \text {houseprice }+\theta_{6}^{+} \text {eastern }+\theta_{7}^{+} \text {pacificnw } \\
& +\theta_{8}^{+} \text {medtrees }+\theta_{0}^{+} \text {oldtrees }+\theta_{10}^{+} \text {signif }+\theta_{11}^{+} \text {popdensity } \\
& +\theta_{12}^{+} \text {medianincome }+\varepsilon^{+}
\end{aligned}
$$

where all variables are defined in Table 2 and the $\theta_{i}^{+}$are coefficients to be estimated. The dependent variable is the consistent measure of the

\begin{tabular}{|c|c|c|c|}
\hline Variable & Description & $\begin{array}{l}\text { Positive observations }(I P>0) \\
\text { Mean } \\
(\min , \max )\end{array}$ & $\begin{array}{l}\text { Negative observations }(I P<0) \\
\text { Mean } \\
(\min , \max )\end{array}$ \\
\hline \multicolumn{4}{|c|}{ Dependent variable in selection equation } \\
\hline amenity & 1 if implicit price $(I P)$ is positive and 0 if $I P$ is negative & $\begin{array}{l}0.64 \\
(0.00,1.00)\end{array}$ & NA \\
\hline \multicolumn{4}{|c|}{ Dependent variable in meta-equation } \\
\hline IP & Implicit price of tree cover for a $1 \%$ increase $(\$ 2013)$ & $\begin{array}{l}\$ 239.41 \\
(\$ 0.32, \$ 2696.15)\end{array}$ & $\begin{array}{l}-\$ 156.26 \\
(-\$ 895.94,-\$ 0.04)\end{array}$ \\
\hline \multicolumn{4}{|c|}{ Independent variables } \\
\hline onprop & 1 if treecover on property, 0 otherwise & $\begin{array}{l}0.35 \\
(0.00,1.00)\end{array}$ & $\begin{array}{l}0.40 \\
(0.00,1.00)\end{array}$ \\
\hline medtrees $^{\mathrm{a}}$ & $\%$ of county forests aged 40 to 119 years & $\begin{array}{l}69 \\
(8,91)\end{array}$ & $\begin{array}{l}64 \\
(45,91)\end{array}$ \\
\hline oldtrees $^{\mathrm{a}}$ & $\%$ of county forests aged 120 years or older & $\begin{array}{l}11 \\
(0.00,44)\end{array}$ & $\begin{array}{l}16 \\
(0.00,44)\end{array}$ \\
\hline invasive & 1 if invasive species or pathogen, 0 otherwise & $\begin{array}{l}0.80 \\
(0.00,1.00)\end{array}$ & $\begin{array}{l}0.70 \\
(0.00,1.00)\end{array}$ \\
\hline temp & Annual days with temperature above $90^{\circ} \mathrm{F}$ & $\begin{array}{l}15 \\
(0.00,76)\end{array}$ & $\begin{array}{l}14 \\
(3,45)\end{array}$ \\
\hline popdensity & County population density (people/mile ${ }^{2}$ ) & $\begin{array}{l}886 \\
(7,2715)\end{array}$ & $\begin{array}{l}1245 \\
(7,2715)\end{array}$ \\
\hline medianincome & County median income & $\begin{array}{l}\$ 56,084 \\
(\$ 34,000, \$ 81,330)\end{array}$ & $\begin{array}{l}\$ 53,911 \\
(\$ 35,613, \$ 81,330)\end{array}$ \\
\hline treecover & $\%$ tree cover on or near property & $\begin{array}{l}14 \\
(0.10,61)\end{array}$ & $\begin{array}{l}12 \\
(0.00,40)\end{array}$ \\
\hline ctreecover & $\%$ county-level tree cover & $\begin{array}{l}44 \\
(13,66)\end{array}$ & $\begin{array}{l}48 \\
(13,66)\end{array}$ \\
\hline houseprice & Mean sale price of properties ( $\$ 2013$ ) & $\begin{array}{l}\$ 285,138 \\
(\$ 24,576, \$ 494,894)\end{array}$ & $\begin{array}{l}\$ 249,200 \\
(\$ 24,576, \$ 494,894)\end{array}$ \\
\hline eastern $^{\mathrm{b}}$ & 1 if study area is east of Mississippi River, 0 otherwise & $\begin{array}{l}0.69 \\
(0.00,1.00)\end{array}$ & $\begin{array}{l}0.47 \\
(0.00,1.00)\end{array}$ \\
\hline pacificn $w^{\mathrm{b}}$ & 1 if study area is in Oregon or Washington, 0 otherwise & $\begin{array}{l}0.21 \\
(0.00,1.00)\end{array}$ & $\begin{array}{l}0.42 \\
(0.00,1.00)\end{array}$ \\
\hline signif & 1 if tree cover significant at $10 \%$ level, 0 otherwise & $\begin{array}{l}0.66 \\
(0.00,1.00)\end{array}$ & $\begin{array}{l}0.47 \\
(0.00,1.00)\end{array}$ \\
\hline
\end{tabular}
implicit price (effect size) explained in the previous section. The treecover variable represents the tree cover variable from the original hedonic models, and ctreecover is included to consider if tree cover in the greater study area where people work, shop, and recreate also

Table 2

Definitions and summary statistics of variables used to estimate selection equation and meta-equation.

Minimum and maximum of the variables are given in parenthesis.

a Percent of county forest below 40 years of age is the omitted category.

b Omitted category includes the following study locations in the mountain west: Greater Flagstaff area, Arizona; Grand County, Colorado; and Flathead, Lake, Sanders, Lincoln and Missoula Counties, Montana. 
affects the implicit value of tree cover on or near a property. Both of these variables are included as linear and squared terms (treecover ${ }^{2}$ and ctreecover $^{2}$ ) to allow for nonlinear relationships between the implicit value and the tree cover measures.

The mean value of house prices (houseprice) from the original hedonic studies is included to see if implicit values of tree cover are affected by selling prices of properties. Binary variables for studies conducted in the eastern U.S. and Pacific Northwest are included to control for spatial fixed effects in different areas of the country (e.g., the risk of forest fires). The omitted category includes studies conducted in the mountain west. Tree age is included because the age of trees affects the size of the crown and could affect the implicit price of tree cover. The omitted category is young trees ( $<40$ years of age). Finally, a variable is included to see if the significance of implicit price estimates in the original hedonic studies affects the magnitudes of the estimates in meta-equation; all implicit price estimates, statistically significant and insignificant, from the hedonic studies are included in the meta-data.

The selection model estimates Eqs. (5a) and (5b) jointly (Wooldridge, 2002), and we conducted a test for the presence of selection from only using studies with positive implicit prices in the estimation of Eq. (5b):

$H_{o}: \rho=0$ vs $H_{a}: \rho \neq 0$

where $\rho$ is the correlation between the error terms in Eqs. (5a) and (5b) ( $\omega$ and $\varepsilon^{+}$, respectively). If the null hypothesis cannot be rejected, then the meta-equation ( $5 \mathrm{~b}$ ) can be estimated solely, without the selection equation.

A number of robustness analyses are conducted to provide insight into how much confidence can be placed in the meta-equation coefficient estimates and thus conclusions drawn from the meta-analysis. Given that most studies provided multiple implicit-price estimates and these multiple estimates from individual studies cannot be assumed to be independent observations, the meta-equation is estimated using OLS, study fixed effects, random effects and multilevel mixedeffects. In addition, horizontal robustness checks, excluding individual observations or studies (groups of observations) are also conducted (Boyle et al., 2013). The primary focus of these robustness analyses is to consider if the exclusions of observations from the data affects the estimates of the coefficients on treecover and ctreecover. The results of these robustness analyses are reported below.

\section{Results}

Summary statistics for the variables used in the estimation are reported in Table 2 . These data indicate that $64 \%$ of the observations have positive implicit prices. Of the studies with positive implicit prices, the average implicit price for a $1 \%$ change in tree cover is $\$ 239$, and the comparable figure for negative implicit prices is $\$ 156$. Values of the variable treecover for the positive implicit prices range from $0.1 \%$ to $61 \%$ and the comparable range for negative implicit prices is $0 \%$ to $40 \%$.

\subsection{Selection Equation}

Estimation of the Heckman sample selection model (Eqs. (5a) and (5b)) resulted in the conclusion that the null hypothesis of no correlation (Eq. (6)) could not be rejected ( $p=0.93$ ). As there is no sample selection, the primary focus of the analyses reported in this paper is the meta-equation. The results from the estimation of the Heckman selection equations are reported in the Appendix A.

\subsection{Meta-equation Estimation Results and Discussion}

The meta-equation is estimated with White's consistent standard errors (Nelson and Kennedy, 2009). ${ }^{6}$ In this estimation, we found that popdensity and medianincome were insignificant. This is driven in large part by the study-specific auxiliary data being correlated, which reduces the efficiency of the estimation of all coefficient estimates. Thus, we test the null hypothesis that the coefficients on popdensity and medianincome are jointly insignificant in the metaequation:

$H_{o}: \theta_{11}^{+}=\theta_{12}^{+}=0$ vs $H_{0}: \theta_{11}^{+} \neq 0, \theta_{12}^{+} \neq 0$

We could not reject this null hypothesis $(\mathrm{F}=2.11, \mathrm{p}=0.13)$. Given this result, the estimation results reported here are for Eq. (5b) with the popdensity and medianincome variables excluded. ${ }^{7}$

The treecover, treecover ${ }^{2}$, ctreecover and ctreecover $^{2}$ variables all have significant coefficient estimates (Table 3 ). The linear terms of these variables have positive coefficient estimates and the squared terms have negative coefficients. This supports the intuition from previous research that people value tree cover up to a point, but beyond this point tree cover declines in value. This could occur for a variety of reasons, including:

- some shade is good, but too much shade blocks sunlight for lawns and passive solar heating;

- tree cover provides privacy, but too much cover may hamper home security or obscure vistas;

- trees make a home more attractive, but too much tree cover may lead to buildup of mildew and algae on exterior structures and excessive cleanup of leaves and litter;

- trees attract watchable wildlife, but too much tree cover may attract nuisance wildlife;

- trees provide cover from harsh wind and rain, but may break apart in inclement weather or create a wildfire hazard;

There could be a variety of other explanations, but these considerations are consistent with what other investigators have found.

It is interesting to note that the implicit prices of tree cover are higher for eastern study sites (eastern) than for mountain west study sites (the omitted category in the estimation), and implicit prices for Pacific Northwest studies are not significantly different from mountain west studies. This difference could be due to a higher risk of forest fires in the mountain west and Pacific Northwest, a preference for more vistas in the west, a preference for more privacy in the east, or other explanations.

The coefficient for older forests (oldtrees) is positive and significant, indicating significantly higher implicit prices for study sites with older versus younger forests (the omitted category) in the county where the studies were conducted. This suggests people value living in areas of mature forests that provide more shade and may be visually appealing. ${ }^{8}$

\footnotetext{
${ }^{6}$ To account for multiple observations from most studies, we estimated the metaequation using fixed-effects, random-effects, and mixed-effects estimation. The fixedeffects estimation did not work because of collinearity issues. The random-effects and mixed-effects estimations did not change the quantitative and qualitative results for the meta-equation coefficient estimates.

7 We estimated the meta-equation using negative implicit prices as the dependent variable and none of the explanatory variables were significant.

${ }^{8}$ This is an interesting outcome when compared to the result from the selection equation reported in the Appendix. Older trees increase the probability of a negative implicit price, but also increase the magnitude of positive implicit prices. These results suggest the concurrent amenity/disamenity of older trees; more shade and a desirable esthetic, but higher perceived risks with more maintenance costs.
} 
Table 3

Meta-equation coefficient estimates (positive implicit prices, $I P^{+}$).

\begin{tabular}{ll}
\hline Variables & Coefficient estimates \\
\hline treecover & $22.32^{*}$ \\
& $(12.64)$ \\
treecover $^{2}$ & $-0.37^{* *}$ \\
& $(0.18)$ \\
ctreecover & $84.10^{* *}$ \\
& $(35.94)$ \\
ctreecover $^{2}$ & $-1.11^{* *}$ \\
& $(0.47)$ \\
houseprice & -0.0002 \\
& $(0.0007)$ \\
eastern & $1393.97^{* *}$ \\
& $(681.76)$ \\
pacificnw & 351.75 \\
& $(239.73)$ \\
oldtrees & $41.07^{* *}$ \\
& $(17.66)$ \\
medtrees & 5.08 \\
signif & $(4.63)$ \\
intercept & 100.54 \\
$n$ & $(98.15)$ \\
$R^{2}$ & $-2971.9^{* *}$ \\
\hline
\end{tabular}

Robust standard errors are given in parentheses.

* Indicates significance at the $10 \%$ level.

** Indicates significance at the $5 \%$ level.

\subsection{Tree Cover than Maximizes Property Values}

Using the results shown in Table 3, the levels of treecover (tc) and ctreecover (ctc) that maximize implicit prices were computed as:

$\frac{\partial I P^{+}}{\partial t c}=0$ and $\frac{\partial I P^{+}}{\partial c t c}$

The level of treecover that maximizes implicit prices is $30 \%$ with a standard error of $15 \%$ and the comparable level for ctreecover is $38 \%$ with a standard error of $3 \%{ }^{9}$

It is worth noting that treecover ranges from $0.1 \%$ to $61 \%$ in the data used to estimate the meta-equation and the comparable range for ctreecover is $13 \%$ to $66 \%$ (see Table 2 ). Thus, the levels of treecover and ctreecover that maximize implicit prices are within the observed data on tree cover. Increasing tree cover beyond these levels does not result in a negative implicit price; it is just that the implicit prices decline from their maximum values.

An additional consideration is that the mean value of treecover is $14 \%$ (Table 2), while the value that maximizes implicit price for this variable is $30 \%$ (more than one standard deviation below the value that maximizes implicit prices). Further, $14 \%$ tree cover on or near a property is much less for tree cover in the county where the properties are located (44\%, Table 2 ). These relationships support the notion that individual property owners underinvest in trees on their property from both the perspective of individual property owners and a societal perspective.

\footnotetext{
9 The standard errors were approximated using the Marcov Chain Monte-Carlo (MCMC) approach using the Gibbs sampler (Plassmann and Khanna, 2007). This method generates a large number of samples from posterior distributions of coefficient estimates for treecover and ctreecover and posterior distributions of turning points of treecover and ctreecover that maximize the implicit prices. Posterior means and standard deviations are calculated for these finite sample approximations of the sampling distribution of the levels of treecover and ctreecover that maximize implicit prices.
}

\subsection{Robustness of Meta-equation Coefficient Estimates}

Conducting robustness checks in any empirical analysis is always important, but it is particularly important for this analysis when estimation is done with only 68 observations. With a small sample size, a single observation or group of observations (study) has the potential to influence estimation results.

Removal of single observations and re-estimation of the metaequation did not induce major changes in the estimates of the key coefficients for treecover, treecoversq, ctreecover and ctreecoversq. None of these coefficient estimates changed sign, the average change in the magnitude of the estimated coefficients for these variables is only $4 \%$, and there were three occurrences where treecover and treecoversq became insignificant (Table 4). The only variable that exhibited substantial sensitivity to removing observations is houseprice with an average effect of $19 \%$, but this variable is insignificant in the original meta-equation reported in Table 3 and only becomes significant in two instances in the observation-removal robustness analysis.

In contrast, all coefficient estimates for treecover, treecoversq, ctreecover and ctreecoversq exhibited more variability when studies (sets of observations) are removed from the estimation. Recall, there are thirteen studies with positive implicit price estimates and the number of observations range from one to ten per study (Table 1). Here the coefficient estimates for treecover, treecoversq, ctreecover and ctreecoversq sometimes changed significance or sign up to two times; the average change in coefficient estimates ranges 35\% (treecover) to 56\% (ctreecover) (Table 5).

Given these study sensitivity results, it is logical to ask which studies are affecting the estimation. This analysis is conducted by looking at the changes in the level of tree cover that maximizes implicit prices (Table 6). Recall the level of treecover that maximizes implicit prices, based on the full estimates with all observations, is $30 \%$ and the comparable value for ctreecover is $38 \%$. The good news is that only three studies resulted in changes of the level of treecover by more than $10 \%$, but the bad news is that the effects were quite large: $51 \%$ (Holmes et al., 2006), -26\% (Netusil et al., 2010) and - 11\% (Drake-McLaughlin and Netusil, 2011). The effects on the level of ctreecover were generally smaller; again, two studies resulted in greater than $10 \%$ changes in the maximum implicit price $(-13 \%$ - Holmes et al., 2006 and 15\% Holmes et al., 2010). It is important to note that studies with the largest percentage deviations in the levels of treecover that maximize implicit prices, when their observations are removed from the estimation, have some of the largest numbers of observations in the data (9Holmes et al., 2006; 10 - Holmes et al., 2010; 7 - Netusil et al., 2010; 7 - Drake-McLaughlin and Netusil, 2011). The key insight from the study robustness checks is that while coefficient estimates varied, in most cases the linear and square term coefficient estimates moved in a relationship that does not change the levels of treecover and ctreecover that maximize implicit prices.

The violations of robustness do not imply that the influential studies should be removed from the analysis, nor do they imply that the meta-analysis results are invalid, but they do suggest that the findings reported here should be interpreted as preliminary and with caution. More studies are needed to add spatial breadth and location-specific depth of implicit price estimates to confirm the preliminary findings presented here. It is crucial that the future studies focus on percent tree cover as the key variable so that the new empirical estimates can be merged with the empirical estimates used here to estimate a new meta-equation.

\section{Conclusions}

This study finds a nonlinear relationship between the implicit value of tree cover and two types of tree canopy cover: tree cover on or near a property, and tree cover in the county where a property is located. This nonlinear relationship allows the computation of the 
Table 4

Observation robustness (removing one observation at a time from estimation).

\begin{tabular}{|c|c|c|c|}
\hline Variables & $\begin{array}{l}\text { Number of } \\
\text { times sign } \\
\text { changed }\end{array}$ & $\begin{array}{l}\text { Number of times } \\
\text { significance changed } \\
\text { (at 10\%) }\end{array}$ & $\begin{array}{l}\text { Absolute, percent changes in } \\
\text { coefficient magnitudes } \\
\text { Average } \\
\text { (min, max) }\end{array}$ \\
\hline treecover & 0 & 3 & $\begin{array}{l}4 \% \\
(0,52)\end{array}$ \\
\hline treecover $^{2}$ & 0 & 3 & $\begin{array}{l}4 \% \\
(0,39)\end{array}$ \\
\hline ctreecover & 0 & 0 & $\begin{array}{l}4 \% \\
(0,21)\end{array}$ \\
\hline ctreecover $^{2}$ & 0 & 0 & $\begin{array}{l}4 \% \\
(0,19)\end{array}$ \\
\hline houseprice & 2 & 0 & $\begin{array}{l}19 \% \\
(0,177)\end{array}$ \\
\hline eastern & 0 & 1 & $\begin{array}{l}5 \% \\
(0,52)\end{array}$ \\
\hline pacificnw & 0 & 6 & $\begin{array}{l}5 \% \\
(0,40)\end{array}$ \\
\hline oldtrees & 0 & 1 & $\begin{array}{l}4 \% \\
(0,31)\end{array}$ \\
\hline medtrees & 0 & 2 & $\begin{array}{l}7 \% \\
(0,179)\end{array}$ \\
\hline signif & 0 & 0 & $\begin{array}{l}7 \% \\
(0,55)\end{array}$ \\
\hline
\end{tabular}

Minimum and maximum of the variables are given in parentheses.

amount of property-level and county-level tree cover that maximizes the implicit value of tree canopy cover: $30 \%$ for tree cover on or near a property, and $38 \%$ at the county level. This pattern of results suggests that property owners prefer more tree cover in the general area where they work, shop and recreate, as a public good, than on their own property, as a private good. This discrepancy may be due to the fact that homeowners generally pay all of the planting and maintenance costs and bear most of the perceived risks (i.e., wildfire and storm damage) for trees located on their property. When these costs and risks are either borne by other private landowners, or are shared by all taxpayers for trees located on public land, higher levels of county-level tree cover are preferred.

The finding that the implicit value of tree cover is maximized at about $38 \%$ for county-level cover is consistent with the often-cited $40 \%$ tree cover espoused by American Forests as an ecological goal for communities on the East Coast and Pacific Northwest of the United States. The average urban tree cover in the U.S. is currently about $35 \%$ (Nowak et al., 2010). Therefore, in many areas, overall tree cover could be rightly increased with a concomitant positive effect on residential property values.

The preference for old trees (more than 120 years old) found in this meta-analysis is another interesting result. A simplistic view of land development may be to cut down old trees and then plant new ones upon completion of construction rather than invest in protection and restorative care of old trees; here again, this may be indicative of underinvestment in community tree cover. These veteran trees are much more ecologically valuable than young trees for carbon storage, air pollution abatement, stormwater interception, and energy conservation, and these results provide evidence that they have more amenity value too. Thus, communities might wish to consider public outreach programs, zoning policies, and tax incentives to protect and maintain older tress. Although such endeavors come at a cost for the community, these costs might be recouped in part through additional real estate tax revenues on higherappraising residential property.

While the findings of this study may be helpful to local officials involved in planning community forestry programs, we expect that decision-making by both community planners and households will become more complex in the future due to various outcomes
Table 5

Study robustness (removing one study at a time from estimation).

\begin{tabular}{|c|c|c|c|}
\hline Variable & $\begin{array}{l}\text { Number of } \\
\text { times sign } \\
\text { changed }\end{array}$ & $\begin{array}{l}\text { Number of times } \\
\text { significance changed } \\
\text { (at 10\%) }\end{array}$ & $\begin{array}{l}\text { Absolute, percent changes in } \\
\text { coefficient magnitudes } \\
\text { Average } \\
\text { (min, max) }\end{array}$ \\
\hline treecover & 0 & 3 & $\begin{array}{l}35 \% \\
(1,97)\end{array}$ \\
\hline treecover $^{2}$ & 2 & 2 & $\begin{array}{l}46 \% \\
(3,167)\end{array}$ \\
\hline ctreecover & 1 & 1 & $\begin{array}{l}56 \% \\
(1,291)\end{array}$ \\
\hline ctreecover $^{2}$ & 1 & 1 & $\begin{array}{l}55 \% \\
(0,294)\end{array}$ \\
\hline houseprice & 5 & 1 & $\begin{array}{l}225 \% \\
(4,930)\end{array}$ \\
\hline eastern & 2 & 2 & $\begin{array}{l}65 \% \\
(6,272)\end{array}$ \\
\hline pacificnw & 1 & 2 & $\begin{array}{l}66 \% \\
(2,315)\end{array}$ \\
\hline oldtrees & 1 & 2 & $\begin{array}{l}59 \% \\
(7,244)\end{array}$ \\
\hline medtrees & 2 & 3 & $\begin{array}{l}88 \% \\
(0,443)\end{array}$ \\
\hline signif & 0 & 0 & $\begin{array}{l}19 \% \\
(0,95)\end{array}$ \\
\hline
\end{tabular}

Minimum and maximum of the variables are given in parentheses.

anticipated from a changing climate. On the one hand, a hotter climate may increase the value of tree cover for its ability to shade and cool homes. This preference may be most acute in urban areas that are vulnerable to "heat island" effects. Further, tree canopy and forested riparian buffers intercept stormwater, helping to mitigate the flooding and water quality effects of runoff. On the other hand, climate change may increase the frequency and severity of extreme weather events, which could lead to an increase in storm damage to trees, causing increased power outages and debris cleanup costs. This may push communities to think twice about maintaining large, mature trees in residential areas. Consequently, the future may bring complex challenges to residential property owners and community forest planners alike. Because tree-cover considerations may vary by geographic location, preferences for property-level and county-level tree cover may become even more nuanced and, over time, local planners may find it useful to engage residents to discuss and refine the goals of community forestry programs.

Table 6

Changes in implicit prices by study for study robustness.

\begin{tabular}{lll}
\hline Study & \multicolumn{2}{l}{ Percent changes } \\
\cline { 2 - 3 } & treecover & ctreecover \\
\hline Coley (2005) & $4 \%$ & $-2 \%$ \\
Dimke (2008) & NA & $-2 \%$ \\
Drake-McLaughlin and Netusil (2011) & $-11 \%$ & $1 \%$ \\
Holmes et al. (2006) & $51 \%$ & $-13 \%$ \\
Holmes et al. (2010) & $2 \%$ & $15 \%$ \\
Kim and Wells (2005) & $2 \%$ & $-1 \%$ \\
Mansfield et al. (2005) & $0 \%$ & $5 \%$ \\
Netusil et al. (2010) & $-26 \%$ & $0 \%$ \\
Paterson and Boyle (2002) & $\mathrm{NA}$ & $-3 \%$ \\
Price et al. (2010) & $-1 \%$ & $1 \%$ \\
Sander et al. (2010) & $2 \%$ & $-2 \%$ \\
Sander and Haight (2012) & $1 \%$ & $-1 \%$ \\
Stetler et al. (2010) & $7 \%$ & $-4 \%$ \\
\hline
\end{tabular}

NA indicates coefficient estimate of treecovers $q$ and ctreecovers $q$ have the wrong signs and are insignificant so tree cover that maximizes implicit prices could not be calculated. 


\section{Appendix A. Heckman Selection Equation Estimation}

Table A1

Joint estimation of selection equation and meta-equation.

\begin{tabular}{|c|c|c|}
\hline & Variable & Coefficient \\
\hline \multirow[t]{8}{*}{ Selection equation } & onprop & $\begin{array}{l}3.27 \\
(4.03)\end{array}$ \\
\hline & onprop* medtrees & $\begin{array}{l}0.003 \\
(0.06)\end{array}$ \\
\hline & onprop* ${ }^{*}$ oldtrees & $\begin{array}{l}-0.19^{* *} \\
(0.07)\end{array}$ \\
\hline & onprop*invasive & $\begin{array}{l}-2.87 \\
(2.69)\end{array}$ \\
\hline & onprop* temp & $\begin{array}{l}0.01 \\
(0.05)\end{array}$ \\
\hline & popdensity & $\begin{array}{l}0.0004^{* *} \\
(0.0002)\end{array}$ \\
\hline & medianincome & $\begin{array}{l}0.00002^{*} \\
(0.00001)\end{array}$ \\
\hline & intercept & $\begin{array}{l}-1.03 \\
(0.71)\end{array}$ \\
\hline \multirow[t]{14}{*}{ Meta-equation } & treecover & $\begin{array}{l}19.09 \\
(11.92)\end{array}$ \\
\hline & treecover $^{2}$ & $\begin{array}{l}-0.33^{*} \\
(0.17)\end{array}$ \\
\hline & ctreecover & $\begin{array}{l}49.23 \\
(40.06)\end{array}$ \\
\hline & ctreecover $^{2}$ & $\begin{array}{l}-0.70 \\
(0.51)\end{array}$ \\
\hline & houseprice & $\begin{array}{l}-0.002 \\
(0.002)\end{array}$ \\
\hline & eastern & $\begin{array}{l}735.87 \\
(1132.8)\end{array}$ \\
\hline & pacificnw & $\begin{array}{l}397.96 \\
(667.9)\end{array}$ \\
\hline & medtrees & $\begin{array}{l}11.72 \\
(8.55)\end{array}$ \\
\hline & oldtrees & $\begin{array}{l}19.53 \\
(23.83)\end{array}$ \\
\hline & signif & $\begin{array}{l}112.53 \\
(94.06)\end{array}$ \\
\hline & popdensity & $\begin{array}{l}-0.21 \\
(0.15)\end{array}$ \\
\hline & medianincome & $\begin{array}{l}0.005 \\
(0.02)\end{array}$ \\
\hline & intercept & $\begin{array}{l}-1696.32 \\
(1151.4)\end{array}$ \\
\hline & $\rho$ & $\begin{array}{l}-0.05 \\
(0.52)\end{array}$ \\
\hline
\end{tabular}

Robust standard errors are given in parentheses.

* Indicates significance at the $10 \%$ level.

** Indicates significance at the $5 \%$ level.

\section{References}

Bentz, B., 2008. Western U.S. bark beetles and climate change. U.S. Department of Agriculture, Forest Service, Climate Change Resource Center (http://www.fs.fed.us/ccrc/ topics/bark-beetles.shtml, accessed 11.02.2014).

Boyle, K.J., Parmeter, C.F., Boehlert, B.B., Paterson, R.W., 2013. Due diligence in metaanalyses to support benefit transfers. Environ. Resour. Econ. 55 (23), 357-386

Cho, S.-H., Poudyal, N.C., Roberts, R.K., 2008. Spatial analysis of the amenity value of green open space. Ecol. Econ. 66 (2), 403-416.

Cho, S.-H., Kim, S.G., Roberts, R.K., Jung, S., 2009. Amenity values of spatial configurations of forest landscapes over space and time in the Southern Appalachian Highlands. Ecol. Econ. 68 (10), 2646-2657.

Cho, S.H., Lambert, D., Kim, S., Roberts, R., Park, W., 2011. Relationship between value of open space and distance from housing locations within a community. J. Geogr. Syst. 13 (4), 393-414.

Coley, M.C., 2005. House and Landscape Value: An Application of Hedonic Pricing Technique Investigating Effects of Lawn Area on House Selling Price (MS Thesis) The University of Georgia.

Dale, V.H., Joyce, L.A., McNulty, S., Neilson, R.P., Ayres, M.P., Flannigan, M.D., Hanson, P.J., Irland, L.C., Lugo, A.E., Peterson, C.J., Simberloff, D., Swanson, F.J., Stocks, B.J., Wotton, B.M., 2001. Climate change and forest disturbances. Bioscience 51 (9), $723-734$.

Dimke, K.C., 2008. Valuation of Tree Canopy on Property Values of Six Communities in Cincinnati, Ohio (PhD Dissertation) The Ohio State University.
Drake-McLaughlin, N., Netusil, N.R., 2011. Valuing walkability and vegetation in Portland, Oregon. In: von Haefen, R.H. (Ed.), Twenty-second Interim Report and Proceedings from the Annual Meeting, W2133, pp. 173-201.

Frankel, S.J., 2008. Forest Plant Diseases and Climate Change. U.S. Department of Agriculture, Forest Service, Climate Change Resource Center (http://www.fs.usda.gov/ccrc/ topics/plant-diseases.shtml, accessed 11.02.2014).

Ghermandi, A., Nunes, P.A., 2013. A global map of coastal recreation values: results from a spatially explicit meta-analysis. Ecol. Econ. 86, 1-15.

Heckman, J.J., 1979. Sample selection bias as a specification error. Econometrica 47 (1), 153-161.

Holmes, T.P., Murphy, E.A., Bell, K.P., 2006. Exotic forest insects and residential property values. Agric. Resour. Econ. Rev. 35 (1), 155-166.

Holmes, T.P., Murphy, E.A., Bell, K.P., Royle, D.D., 2010. Property value impacts of hemlock woolly adelgid in residential forests. For. Sci. 56 (6), 529-540.

Homer, C., Dewitz, J., Fry, J., Coan, M., Hossain, N., Larson, C., Herold, N., McKerrow, A. VanDriel, J.N., Wickham, J., 2007. Completion of the 2001 national land cover database for the conterminous United States. Photogramm. Eng. Remote Sens. 73 (4), 337-341.

Hope, D., Gries, C., Zhu, W., Fagan, W.F., Redman, C.L., Grimm, N.B., Nelson, A.L., Martin, C., Kinzig, A., 2003. Socioeconomics drive urban plant diversity. Proc. Natl. Acad. Sci. 100 (15), 8788-8792.

Huggett Jr., R.J., 2003. Fire in the Wildland-Urban Interface: An Examination of the Effects of Wildfire on Residential Property Markets (PhD Dissertation) North Carolina State University.

Iverson, L.R., Prasad, A.M., 2001. Potential changes in tree species richness and forest community types following climate change. Ecosystems 4 (3), 186-199.

Johnston, R.J., Besedin, E.Y., Stapler, R., 2014. Enhanced geospatial data for meta-analysis and environmental benefit transfer: an application to water quality improvements. Presented at the Meta-analysis of Economics Research Network, MAER-Net 2014 Athens Colloquium, Athens, Greece.

Kim, Y.S., Wells, A., 2005. The impact of forest density on property values. J. For. 103 (3), 146-151.

Mansfield, C., Pattanayak, S.K., McDow, W., McDonald, R., Halpin, P., 2005. Shades of green: measuring the value of urban forests in the housing market. J. For. Econ. 11 (3), 177-199.

Nelson, J.P., Kennedy, P.E., 2009. The use (and abuse) of meta-analysis in environmental and natural resource economics: an assessment. Environ. Resour. Econ. 42 (3), 345-377.

Netusil, N.R., Chattopadhyay, S., Kovacs, K.F., 2010. Estimating the demand for tree canopy: a second-stage hedonic price analysis in Portland, Oregon. Land Econ. 86 (2), 281-293.

Nowak, D.J., Greenfield, E.J., 2012. Tree and impervious cover change in US cities. Urban For. Urban Green. 11 (1), 21-30.

Nowak, D.J., Stein, S.M., Randler, P.B., Greenfield, E.J., Comas, S.J., Carr, M.A., Alig, R.J., 2010 Sustaining America's urban trees and forests: a forests on the Edge report Gen. Tech. Rep. NRS-62. U.S. Department of Agriculture, Forest Service, Northern Research Station.

Paterson, R.W., Boyle, K.J., 2002. Out of sight, out of mind? Using GIS to incorporate visibility in hedonic property value models. Land Econ. 78 (3), 417-425.

Pickett, S.T., Cadenasso, M.L., Grove, J.M., Booned, C.G., Groffman, P.M., Irwin, E., Kaushal, S.S., Marshall, V., McGrath, B.P., Nilon, C.H., Pouyat, R.V., Szlavecz, K., Troy, A., Warren, P., 2011. Urban ecological systems: scientific foundations and a decade of progress. J. Environ. Manag. 92 (3), 331-362.

Plassmann, F., Khanna, N., 2007. Assessing the precision of turning point estimates in polynomial regression functions. Econ. Rev. 26 (5), 503-528.

Prasad, A., Iverson, L.S., Matthews, S., Peters, M., 2009. Atlases of tree and bird species habitats for current and future climates. Ecol. Restor. 27 (3), 260-263.

Price, J.I., McCollum, D.W., Berrens, R.P., 2010. Insect infestation and residential property values: a hedonic analysis of the mountain pine beetle epidemic. Forest Policy Econ. 12 (6), 415-422

Sander, H., Haight, R.G., 2012. Estimating the economic value of cultural ecosystem services in an urbanizing area using hedonic pricing. J. Environ. Manag. 113, 194-205.

Sander, H., Polasky, S., Haight, R.G., 2010. The value of urban tree cover: a hedonic property price model in Ramsey and Dakota Counties, Minnesota, USA. Ecol. Econ. 69 (8) 1646-1656.

Schroeder, H., Flannigan, G., Coles, R., 2006. Residents' attitudes toward street trees in the UK and US communities. Arboricult. Urban For. 32 (5), 236-246.

Stetler, K.M., Venn, T.J., Calkin, D.E., 2010. The effects of wildfire and environmental amenities on property values in northwest Montana, USA. Ecol. Econ. 69 (11), 2233-2243.

Taylor, L.O., 2003. The hedonic method. In: Champ, P., Boyle, K., Brown, T. (Eds.), A primer on nonmarket valuation. Kluwer Academic Publishers, New York.

Troy, A.R., Grove, J.M., O'Neil-Dunne, J.P., Pickett, S.T., Cadenasso, M.L., 2007. Predicting opportunities for greening and patterns of vegetation on private urban lands. Environ. Manag. 40 (3), 394-412.

U.S. Department of Labor, Bureau of Labor Statistics, 2015. Consumer Price Index Data from 1913 to 2016. (http://www.usinflationcalculator.com/inflation/consumerprice-index-and-annual-percent-changes-from-1913-to-2008/, accessed July 2013).

Wolf, K.L., 2004. Trees and business district preferences: a case study of Athens, Georgia, US. J. Arboric. 30 (6), 336-346.

Woodall, C.W., Oswalt, C.M., Westfall, J.A., Perry, C.H., Nelson, M.D., Finley, A.O., 2009. An indicator of tree migration in forests of the Eastern United States. For. Ecol. Manag. 257 (5), 1434-1444.

Wooldridge, J., 2002. Econometric Analysis of Cross Section and Panel Data. MIT Press, Cambridge. 